\title{
PENGARUH LINGKUNGAN KERJA DAN DISIPLIN KERJA TERHADAP KINERJA KARYAWAN
}

\author{
I P. A. Septiawan ${ }^{1}$, K. K. Heryanda ${ }^{2}$ \\ 1,2Jurusan Manajemen, Universitas Pendidikan Ganesha, Indonesia \\ e-mail: iputuadiseptiawan@gmail.com, krisna.heryanda@undiksha.ac.id
}

\begin{abstract}
Abstrak
Penelitian ini bertujuan untuk menguji pengaruh (1) lingkungan dan disiplin kerja tehadap kinerja karyawan, (2) lingkungan kerja terhadap disiplin kerja, (3) lingkungan kerja tehadap kinerja karyawan, dan (4) disiplin kerja terhadap kinerja karyawan pada CV Puspa. Desain penelitian yang digunakan pada penelitian ini adalah kuantitatif kausal. Subjek penelitian ini adalah karyawan pada CV Puspa dan objeknya adalah lingkungan kerja, disiplin kerja dan kinerja karyawan. Populasi dalam penelitian ini adalah karyawan CV Puspa yang berjumlah 76 orang. Semua populasi dijadikan unit pengamatan, oleh karena itu penelitian ini termasuk penelitian populasi. Data dikumpulkan dengan teknik kuesioner, kemudian dianalisis dengan analisis jalur. Hasil penelitian menunjukan bahwa, (1) lingkungan dan disiplin kerja berpengaruh positif terhadap kinerja karyawan, (2) lingkungan kerja berpengaruh positif terhadap disiplin kerja, (3) lingkungan kerja berpengaruh positif terhadap kinerja karyawan, dan (4) disiplin kerja berpengaruh positif terhadap kinerja karyawan pada CV Puspa.
\end{abstract}

Kata kunci : disiplin kerja, kinerja karyawan, lingkungan kerja

\section{Abstract}

This study aims to examine the effect of (1) work environment and discipline on employee performance, (2) work environment on work discipline, (3) work environment on employee performance, and (4) work discipline on employee performance on CV Puspa. The research design used in this study is causal quantitative. The subjects of this research are employees at CV Puspa and the object is the work environment, work discipline and employee performance. The population in this research is 76 Puspa employees. All populations are made as observation units, therefore this study is included as population research. Data collected by questionnaire technique, then analyzed by path analysis. The results showed that, (1) work environment and discipline had a positive effect on employee performance, (2) work environment had a positive effect on work discipline, (3) work environment had a positive effect on employee performance, and (4) work discipline had a positive effect on performance employee at CV Puspa.

Keyword : work discipline, employee performance, work environment

\section{Pendahuluan}

Perusahaan pada umumnya didirikan dengan tujuan dapat melangsungkan hidupnya dan untuk memperoleh keuntungan yang maksimal. Perusahaan akan dapat mencapai tujuannya dengan efektif apabila orang-orang yang terlibat dalam perusahaan baik secara individu maupun kelompok mampu melaksanakan pekerjaan dan tanggung jawab yang dibebankan kepadanya dengan baik. Keberhasilan suatu perusahaan atau organisasi dalam mencapai tujuanya tidak terlepas kaitanya dari sumber daya manusia yang dimiliki, karena sumber daya manusia yang akan mengatur dan mengelola faktor - faktor produksi yang dimiliki perusahaan untuk membantu mencapai tujuan perusahaan itu sendiri. Hal ini dipertegas oleh Ardana (2012: 3), yang menyatakan sumber daya manusia merupakan salah satu penentu keberhasilan perusahaan karena peranan sumber daya manusia itu sebagai aset berharga dalam merencanakan, melaksanakan serta menggendalikan berbagi kegiatan oprasional perusahaan. Keberhasilan perusahaan dalam mengelola sumber daya 
manusia diukur dengan menggunakan kinerja. Kinerja dipengaruhi oleh banyak faktor, diantaranya lingkungan kerja dan disiplin kerja. Hal ini dipertegas oleh Sumadji dan Suartman (2017), yang menyatakan adanya lingkungan kerja yang memadai dan kondusif serta karyawan yang disiplin dalam menaati peraturan diharapkan kinerja karyawan bisa meningkat.

Perusahaan penggilingan padi merupakan perusahaan yang digerakkan dengan tenaga motor penggerak dan ditujukan serta di gunakan untuk mengolah padi menjadi beras. Di kawasan Jembrana saat ini sedang berkembang usaha pengelolan padi menjadi beras atau penggilingan padi yang dilakukan oleh tiga perusahaan yaitu, UD Abdi Tunggal dengan pencapaian kinerja 3.301 ton (Tercapai), UD Ayu Mandiri dengan pencapaian kinerja 2.906 ton (Tercapai) dan CV Puspa dengan pencapaian kinerja 1.922 ton (Belum Tercapai). Hal tersebut menunjukkan bahwa perusahaan CV Puspa belum mencapai standar kinerja karena pencapaian kinerja perusahaan di bawah standar kinerja yang telah ditetapkan oleh perusahaan. Oleh karena itu, fokus penelitian ini dilakukan di perusahaan CV puspa. CV Puspa merupakan perusahaan yang bergerak di bidang industri pengelolan padi menjadi beras atau penggilingan padi (Rice Miling Unit). Perusahaan ini didirikan oleh Bapak I Ketut Sukadana, ST pada tahun 1986 yang berada di Jl. Patih Jelantik No.109 Br. Taman, Desa Batuagung, Kecamatan Jembrana, Kabupaten Jembrana, Bali. CV Puspa memiliki karyawan sebanyak 76 orang. Berdasarkan hasil obesrvasi awal yang telah dilakukan di CV Puspa menunjukkan bahwa kinerja karyawan pada CV Puspa belum memenuhi standar yang telah ditetapkan oleh perusahaan hal ini disebabkan karena pencapaian kinerja karyawan masih di bawah standar kinerja yang telah ditetapkan oleh perusahaan. Hal ini dapat dilihat dari individu karyawan baik unit kerja produksi, keuangan, dan pemasaran semuanya belum mencapai standar karena pencapian kinerja karyawan masih dibawah standar kinerja yang telah ditetapkan oleh perushaan. Oleh karena itu permasalahan kinerja karyawan menjadi permasalahan utama pada perusahaan CV Puspa. Peningkatkan kerja harus dilakukan karena adanya kesenjangan antara prestasi kerja yang diharapkan dengan kenyataan yang terjadi. Kinerja yang dimiliki oleh karyawan dituntut untuk terus meningkat. Salah satu cara untuk mempertahankan atau meningkatkan kinerja karyawan dapat dilakukan dengan mengevaluasi kinerja karyawan dan memperhatikan permasalahan yang dapat mempengaruhi kinerja karyawannya seperti lingkungan kerja dan disiplin kerja.

Berdasarkan penelitian pendahuluan melalui kuesioner awal yang disebar pada 10 karyawan dapat diperoleh data mengenai lingkungan kerja fisik dan lingkungan kerja non fisik menunjukkan bahwa dilihat dari individu karyawan, $70 \%$ karyawan menyatakan tidak nyaman dan yang menyatakan cukup nyaman hanya 30\%. Dari data ini dapat dilihat bahwa sebagaian besar responden menyatakan lingkungan kerjanya tidak nyaman oleh karena itu dari segi kenyamanan karyawan menjadi permasalahan. Akan tetapi kalau dilihat perdimensi lingkungan kerja baik itu lingkungan kerja fisik maupun lingkungan kerja non fisik semuanya menyatakan sangat tidak nyaman.

Hal ini juga didukung dengan pengamatan langsung yang telah dilakukan. Jadi, diketahui bahwa salah satu lingkungan kerja fisik yang membuat karyawan merasa kurang nyaman saat melakukan pekerjaan terlihat pada pencahayaan di ruang kerja yang kurang maksimal yang disebabkan karena sedikit lampu yang terpasang didalam ruangan tersebut. pencahayaan yang kurang juga dikarenakan disain bangunan yang terlalu tinggi. Selain itu minimnya pentilasi udara pada ruang pekerjaan yang mengakibatkan sirkulasi keluar masuknya udara menjadi sedikit. Begitu juga yang terlihat pada keadaan langusng di dalam ruang pekerjaan mengenai penataan ruangan yang kurang rapi dan kurangnya kebersihan dalam lingkungan kerja sehingga mengakibatkan semangat kerja karyawan menurun dan memngganggu kenyamanan karyawan saat bekerja. Selain lingkungan kerja fisik lingkungan kerja non fisik juga dapat mempengarui kurang nyamannya karyawan saat bekerja, yang terlihat pada tidak tercapainya hubungan yang baik antara karyawan atupun atasan dikarenakan sering tercadinya miss comunication dalam pendistribusian produk dan gejala sikap dan prilaku sosial yang nampak pada karyawan yang tidak berkomunikasi dengan 
harmonis dan sering curiga dengan sesama karyawan. Jika kondisi lingkungan kerja fisik maupun lingkungan kerja non fisik yang ada di perusahaan tidak diperbaiki hal ini akan berdampak pada menurunnya tingkat kehadiran karyawan yang disebabkan ketidaknyamanan pada saat bekerja.

Selain faktor lingkungan kerja terdapat faktor disiplin kerja yang menjadi faktor lain yang mempengruhi kinerja karyawan karena disiplin kerja sangat diperlukan dalam upaya peningkatkan kinerja karyawan. Dari hasil observasi yang sudah dilakukan diperoleh informasi bahwa masih ada karyawan yang menunjukan disiplin kerja yang rendah. Rendahnya disiplin kerja karyawan pada CV Puspa dapat dibuktikan pada data absensi karyawan. Hal tersebut menunjukkan bahwa tingkat absensi dari individu karyawan pada bulan Agustus 2018 memiliki katagori absensi yang tidak disiplin, dan dalam hal ini absensi karyawan merupakan salah satu unsur disiplin kerja pada bagian pelanggaran peraturan kerja. Hal ini juga didukung dengan melihat keadaan langsung para karyawan di perusahaan, dimana masih ditemukannya karyawan yang masuk kerja terlambat, pulang tidak sesaui waktu, dan karyawan sering mengulur waktu istirahat sehingga mempengaruhi tingkat kinerja karyawan dalam mencapai tujuan organiasi perusahaan. Kurangnya disiplin kerja karyawan berampak pada kinerja karyawan yang mengakibatkan kinerjanya menjadi rendah. Karyawan yang disiplin dalam bekerja sejak berangkat, saat kerja dan pulang kerja serta bekerja sesuai aturan biasanya memilki kinerja yang baik.

Penelitian ini bertujuan untuk menguji pengaruh (1) Lingkungan dan disiplin kerja terhadap kinerja karyawan, (2) Lingkungan kerja terhadap disipli kerja, (3) Lingkungan kerja terhadap kinerja karyawan, dan (4) Disiplin kerja terhadap kinerja karyawan pada CV Puspa.

Pendapat ahli pakar sumber daya manusia yang mendukung kinerja sebagai output atau hasil adalah Wibowo (2012) dan Mangkunegara (2011). Menurut Wibowo (2012), kinerja adalah bagimana cara seseorang melakukan pekerjaan dan hasil yang diperoleh dari pekerjaan tersebut. Dengan kata lain kinerja tidak menyangkut bagiamana proses pekerjaan itu berlangsung, namun menyangkut hasil yang dicapai dari proses pekerjaan tersebut. Menurut Mangkunegara (2011), kinerja adalah hasil kerja secara kualitas dan kuantitas yang dicapai oleh seorang pegawai dalam melaksanakan tugasnya sesuai dengan tanggung jawab diberikan kepadanya. Sedangkan ahli yang mendukung kinerja itu adalah outcome adalah Berdardian dan Russell (1993: 279), yang mendifinisikan pengertian kinerja yaitu sebagai catatan mengenai outcome yang dihasilkan dari suatu aktivitas tertentu, selama kurun waktu tertentu. Berdasarkan pendapat para ahli manajemen sumber daya manusia di atas, maka dapat disimpulkan bahwa kinerja adalah catatan outcome yang dihasilkan oleh seseorang dari fungsi suatu pekerjaan selama periode waktu tertentu. Pada penelitian ini konsep atau pengertian kinerja mengacu pada pendapat Berdardian dan Russell (1993: 279). Indikator kinerja menurut Putra (2016) diukur dengan: (1) hasil kerja yang terdiri dari indikator (a) kuantitas hasil kerja dan (b) kualitas hasil kerja, (2) perilaku kerja yang terdiri dari indikator (a) inisiatif dalam mengembangkan ide-ide dan (b) loyalitas karyawan terhadap perushaan, dan (3) kualitas pribadi yang terdiri dari indikator (a) melaksanakan tugas tanpa bantuan rekan kerja, (b) wawasan karyawan mengenai pekerjaan, dan (c) menyelesaikan pekerjaan dengan rekan kerja.

Lingkungan kerja dan disiplin kerja berhubungan atau berpengaruh terhadap kinerja karyawan karena lingkungan kerja yang nyaman akan membuat orang betah bekerja dan fokus serta ditambah dengan karyawan selalu mentaati peraturan kerja, norma, dan nilai maka kinerja karyawan akan meningkat. Hal ini didukung oleh teori yang diungkapkan oleh Sumadji dan Suartman (2017), menyatakan bahwa adanya lingkungan kerja yang memadai dan kondusif serta karyawan yang disiplin dalam menaati peraturan diharapkan kinerja karyawan bisa meningkat. Hal ini juga didukung penelitian yang dilakuakan oleh Ferawati (2017), menunjukan bahwa lingkungan kerja dan dan disiplin kerja berpengaruh signifikan terhadap kinerja karyawan. Lingkungan kerja yang nyaman dan kedisiplinan yang tinggi akan meningkatkan kinerja karyawan. 
Dari hasil kajian pustaka membaca teori dan penelitian orang lain, maka dapat disimpulkan bahwa hubungan antara lingkungan kerja dan disiplin kerja terhadap kinerja karyawan memiliki hubungan positif dan searah, dimana jika karyawan memiliki di lingkungan kerja yang baik dan disiplin kerja yang tinggi maka akan mempengaruhi kinerja karyawan akan lebih baik juga, namun apabila lingkungan kerja karyawan dan disiplin kerja yang dimiliki karyawan buruk maka kinerja karyawan akan menurun.

Dari hasil kajian pustaka membaca teori dan penelitian orang lain, maka dapat disimpulkan bahwa hubungan lingkungan kerja terhadap disiplin kerja memiliki hubungan positif dan searah karena penciptaan lingkungan kerja yang menyenangkan akan mendorong semangat kerja dan dan disiplin kerja sehingga karyawan merasa memiliki tanggung jawab terhadap semua pekerjaan. Apabila lingkungan kerja yang dimiliki oleh perusahan itu kurang nyaman dan kondusif, maka karyawan akan tidak merasa nyaman dalam melaksanakan pekerjaan dan akan sering melanggar peraturan kerja di perusahaan.

Pengertian mengenai lingkungan kerja diungkapkan oleh Zainul dan Taufiq (2012: 82), yang menyatakan bahwa lingkungan kerja merupakan keadaan tempat kerja pegawai baik secara fisik maupun non fisik yang dapat mempengaruhi pegawai saat bekerja. Senada dengan pendapat diatas, menurut Nitisemito (2008), lingkungan kerja sebagai segala sesuatu yang ada disekitar para pekerja yang dapat mempengaruhi dirinya dalam menjalankan tugas-tugas yang diberikan baik fisik maupun non fisik.

Dari pendapat para ahli di atas, maka dapat disimpulkan bahwa lingkungan kerja adalah kondisi kerja yang dirasakan karyawan pada saat bekerja, baik yang berbentuk lingkungan fisik maupun non fisik. Pada penelitian ini konsep atau pengertian kinerja mengacu pada pendapat Sidanti (20015: 46). Indikator yang digunakan untuk mengukur lingkungan kerja menurut Sedarmayanti (2007: 21), terdiri dari dua dimensi (1) lingkungan kerja fisik dengan indikator (a) peralatan kerja, (b) suasana kerja, dan (c) teknologi. (2) Lingkungan kerja non fisik dengan indikator, (a) hubungan dengan atasan, (b) hubungan dengan rekan kerja, dan (c) hubungan dengan bawahan.

Lingkungan kerja berhubungan atau berpengaruh terhadap kinerja karyawan karena lingkungan kerja yang menyenangkan bagi para karyawan melalui peningkatkan hubungan yang harmonis dengan atasan, rekan kerja, maupun bawahan, serta didukung oleh sarana dan prasarana yang memadai di tempat kerja akan memberi dampat positif dan bagi karyawan, sehingga kinerja karyawan dapat meningkat. Hal ini juga didukung oleh teori yang diungkapkan Rahmawati, dkk., (2014), yang menyatakan lingkungan kerja yang nyaman, aman dan menyenangkan merupakan salah satu cara perusahaan untuk dapat meningkatkan kinerja para karyawan. Hal ini di dukung oleh penelitian yang dilakukan oleh Nuryasin, dkk., (2016), yang menyatakan bahwa variabel lingkungan kerja berpengaruh signifikan terhadap kinerja karyawan.

Dari hasil kajian pustaka membaca teori dan penelitian orang lain, maka dapat disimpulkan bahwa hubungan lingkungan kerja terhadap kinerja karyawan memiliki hubungan positif dan searah karena lingkungan kerja yang menyenangkan dan memberikan kepuasan serta rasa aman memiliki kecenderungan mempengaruhi peningkatan kinerja. Sedangkan jika lingkungan kerja tidak memadai dapat mengganggu konsentrasi karyawan dalam melaksanaakan pekerjaan dan menimbulkan kesalahan dalam bekerja karyawan dan mengakibatkan kinerja menurun.

Menurut Hasibuan (2012), kedisiplinan adalah kesadaran atau kesedian seseorang mentaati dan melaksanaakan semua peraturan yang sudah ditetapkan oleh perusahaan sesuai dengan norma-norma sosial yang berlaku. Disiplin kerja adalah kepatuhan pada aturan atau perintah yang telah ditetapkan oleh organisasi perusahaan (Sinambela, 2012: 238). Dari beberapa pendapat para ahli di atas, maka dapat disimpulkan bahwa disiplin kerja adalah Sikap ketaatan dan kepatuhan karyawan terhadap peraturan kerja, nilai dan norma yang berlaku di suatu perusahaan tempat mereka bekerja. Pada penelitian ini konsep atau pengertian disiplin kerja mengacu pada pendapat (Sinambela, 2012: 238). 
Dari hasil kajian pustaka membaca teori dan penelitian orang lain, maka dapat disimpulkan bahwa hubungan disiplin kerja terhadap kinerja karyawan memiliki hubungan positif dan searah karena semakian baik disiplin kerja dari seseorang, maka semakin tinggi kinerja yang dicapai. Demikian pula apabila disiplin kerja yang dimiliki oleh individu karyawan rendah, maka karyawaan tidak merasa memiliki tanggung jawab terhadap pekerjaan dan mengakibtkan kinerja karyawan akan menurun.

\section{Metode}

Penelitian ini menggunakan rancangan penelitian kuantitatif kausal. Kuantitatif kausal merupakan penelitian pendekatan ilmiah terhadap pengambilan keputusan manajerial ekonomi yang bertujuan untuk mendapatkan bukti hubungan sebab akibat dan atau pengaruh dari variabel-variabel penelitian. Penelitian ini dilakukan untuk mengetahui pengaruh lingkungan kerja dan disiplin kerja terhadap kinerja karyawan pada CV Puspa. Variabel dalam peneltian ini ada 3 variabel, yaitu Lingkungan kerja $\left(\mathrm{X}_{1}\right)$, Disiplin Kerja $\left(\mathrm{X}_{2}\right)$ sebagai variabel bebas dan Kinerja Karyawan $(Y)$ sebagai vaiabel terikat. Desain penelitian kuantitatif kausal dapat dilakukan dengan langkah-langkah yaitu: (1) merumuskan masalah, (2) mengkaji teori, (3) merumuskan hipotesis, (4) mengumpulkan data, (5) menganalisis data, dan (6) membuat kesimpulan dan saran. Subjek dari penelitian ini adalah karyawan pada CV Puspa. Sedangkan objek dari penelitian ini adalah lingkungan kerja $\left(\mathrm{X}_{1}\right)$ dan disiplin kerja $\left(\mathrm{X}_{2}\right)$ terhadap kinerja karyawan $(\mathrm{Y})$ pada CV Puspa. Populasi dalam penelitian ini adalah karyawan yang bekerja pada CV Puspa yang berjumlah 76 orang karyawan. 76 orang karyawan ini dijadikan unit pengamatan, oleh karena itu penelitian ini merupakan termasuk penelitian populasi.

Adapun metode pengumpulan data yang digunakan dalam penelitian ini adalah melalui kuesioner. Kuesioner adalah teknik pengumpulan data yang dilakukan dengan cara memberi seperangkat pertanyaan atau pernyataan kepada responden untuk menjawabnya (Sugiyono 1999: 135). Kuesinoer digunakan untuk mendapatkan data tentang lingkungan kerja, disiplin kerja, dan kinerja karyawan pada CV Puspa.

Kuesioner sebagai instrumen pengumpulan data ordinal yang merupakan penjabaran dari indikator variabel sebelum digunakan untuk mengumpulkan data terlebih dahulu harus diuji tingkat validitas dan reliabilitasnya. Dalam penelitian ini uji validitas dan reliabilitas dilakukan pada perusahaan yang sejenis dengan perusahaan tempat melakukan penelitian. Instansi sejenis yang dimagsud adalah instansi memiliki kesamaan dalam hal jenis produk maupun deskripsi data. Setelah melakukan pengamatan, maka instansi yang sejenis dengan CV Puspa adalah UD. Abdi Tunggal. Uji validitas dan reliabilitas koesiner dilakukan pada 30 orang karyawan UD. Abdi Tunggal.

Pengujian validitas tiap butir digunakan analisis item, yaitu mengkorelasikan skor tiap butir. Sebelum digunakan sebagai alat mengumpulkan data harus diuji cobakan terlebih dahulu. Uji coba tersebut dilakukan terhadap responden diluar sampel. Instrumen dikatakan valid apabila koefisien korelasi antar butir lebih besar dari 0,30 dengan tingkat kesalahan alpha 0,05. Untuk membantu proses pengolahan data untuk uji validitas dilakukan dengan program Statistical Product and Service Solution (SPSS) for Windows. Kriteria pengujian dapat diuraikan sebagai berikut. (1) Item instrumen dikatakan valid apabila p-value<alpha 0,05 (2) Item instrumen dikatakan tidak valid apabila p-value>alpha 0,05. Sedangkan uji reliabilitas berkaitan dengan masalah adanya kepercayaan yang di peroleh terhadap instrumen penelitian. Suatu instrumen penelitian dikatakan reliabel atau andal jika jawabanya responden atas pertanyaan adalah konsisten atau stabil dari waktu ke waktu. Suatu instrumen dikatakan reliabel apabila memenuhi kriteria pengujian reliabilitas instument dengan menggunakan taraf signifikan $5 \%$. Pengujian reliabilitas instrumen dalam penelitian ini dilakukan secara internal. Sugiyono (2020), mengatakan bahwa pengujian reliabilitas instrument secara internal dapat menggunakan teknik belah dua (split-half) yaitu pengujian reliabilitas internal dapat dilakukan dengan membelah item-item instrument menjadi dua kelompok (ganjil dan genap), kemudian ditotal, dan dicari korelasinya. 
Metode analisis data dalam penelitian ini adalah dengan menggunakan analisis jalur (path analyze). Analisis jalur (path analyze) digunakan untuk mengetahui pengaruh langsung maupun tidak langsung variabel bebas dan variabel terikat. Selain itu, analisis ini digunakan untuk mengetahui besarnya pengaruh total dan pengaruh langsung serta tidak langsung dari variabel Lingkungan Kerja dan Disiplin Kerja terhadap Kinerja Karyawan CV Puspa. Perhitungan analisi jalur dalam penelitian ini dibantu dengan program Statistical Package for Social Science (SPSS) 22.0 for windows.

\section{Hasil Dan Pembahasan}

Hasil uji statistik analisis jalur menunjukkan bahwa $\mathrm{Px}_{2} \mathrm{x}_{1}=0,849$ dan $\mathrm{Pyx}_{2}=0,549$ dengan $p$-value $=0,000<$ alpha 0,05 sehingga sumbangan pengaruh tidak langsung lingkungan kerja $\left(\mathrm{X}_{1}\right)$ dan disiplin kerja $\left(\mathrm{X}_{2}\right)$ terhadap kinerja karyawan $(\mathrm{Y})$ didapat dari pengalian $\mathrm{Px}_{2} \mathrm{x}_{1}$. $\mathrm{Pyx}_{2}$ sehingga hasilnya sebesar 0,466 atau $46,6 \%$.

Berdasarkan hasil perhitungan uji statistik analisis jalur dengan bantuan program SPSS 22.0 for windows, diperoleh hasil $\mathrm{Px}_{2} \mathrm{x}_{1}=0,849$ dengan $p$-value $=0,000<$ alpha 0,05 sehingga keputusannya adalah menolak $\mathrm{Ho}$. Ini artinya lingkungan kerja $\left(\mathrm{X}_{1}\right)$ berpengaruh secara positif dan signifikan terhadap disiplin kerja $\left(X_{2}\right)$ pada CV Puspa. Besar sumbangan pengaruh lingkungan kerja $\left(X_{1}\right)$ terhadap disiplin kerja $\left(X_{2}\right)$ adalah 0,721 atau sebesar $72,1 \%$.

Berdasarkan hasil perhitungan uji statistik analisis jalur dengan bantuan program SPSS 22.0 for windows, diperoleh hasil $\mathrm{Pyx}_{1}=0,308$ dengan $p$-value $=0,020<$ alpha 0,05 sehingga keputusannya adalah menolak Ho. Ini artinya lingkungan kerja $\left(X_{1}\right)$ berpengaruh secara positif dan signifikan terhadap kinerja karyawan $(Y)$ pada CV Puspa. Pada Tabel 2 menunjukkan sumbangan pengaruh langsung lingkungan kerja $\left(X_{1}\right)$ terhadap kinerja karyawan $(Y)$ yaitu 0,094 atau sebesar $9,4 \%$ sehingga besar sumbangan pengaruh lingkungan kerja $\left(X_{1}\right)$ terhadap kinerja karyawan $(Y)$ secara total yaitu 0,451 atau $45,1 \%$.

Berdasarkan hasil perhitungan uji statistik analisis jalur dengan bantuan program SPSS 22.0 for windows, diperoleh hasil $\mathrm{Pyx}_{2}=0,549$ dengan $p$-value $=0,000<$ alpha 0,05 sehingga keputusannya adalah menolak Ho. Ini artinya disiplin kerja $\left(X_{2}\right)$ berpengaruh secara positif dan signifikan terhadap kinerja karyawan (Y) pada CV Puspa. Pada Tabel 2 menunjukkan sumbangan pengaruh langsung disiplin kerja $\left(\mathrm{X}_{2}\right)$ terhadap kinerja karyawan $(\mathrm{Y})$ yaitu 0,301 atau sebesar $30,1 \%$.

Output SPSS analisis jalur pengaruh lingkungan kerja $\left(X_{1}\right)$ dan disiplin kerja $\left(X_{1}\right)$ terhadap kinerja karyawan (Y) pada CV Puspa nampak pada tabel 1.

Tabel 1 Output SPSS analisis jalur pengaruh lingkungan kerja $\left(X_{1}\right)$ dan disiplin kerja $\left(X_{1}\right)$ terhadap kinerja karyawan $(\mathrm{Y})$

\begin{tabular}{cccc}
\hline Parameter & Koefisien & P-Value & Alpha $(\alpha)$ \\
\hline $\mathrm{Ryx}_{1} \mathrm{x}_{2}$ & 0,874 & 0,000 & 0,05 \\
\hline $\mathrm{R}^{2} \mathrm{yx}_{1} \mathrm{x}_{2}$ & 0,763 & - & 0,05 \\
\hline $\mathrm{Px}_{1} \mathrm{x}_{2}$ & 0,849 & 0,000 & 0,05 \\
\hline $\mathrm{P}^{2} \mathrm{x}_{1} \mathrm{x}_{2}$ & 0,721 & - & 0,05 \\
\hline $\mathrm{Pyx}_{1}$ & 0,308 & 0,007 & 0,05 \\
\hline $\mathrm{P}^{2} \mathrm{yx}_{1}$ & 0,094 & - & 0,05 \\
\hline $\mathrm{Pyx}_{2}$ & 0,549 & 0,000 & 0,05 \\
\hline $\mathrm{P}^{2} \mathrm{yx}_{2}$ & 0,301 & - & 0,05 \\
\hline $\mathrm{Px}_{2} \varepsilon_{1}$ & 0,151 & - & - \\
\hline $\mathrm{Py}_{2}$ & 0,237 & - & - \\
\hline
\end{tabular}

Sumber: Pengelolaan Data SPSS

Struktur hubungan pada penelitian ini nampak pada Gambar 1. 


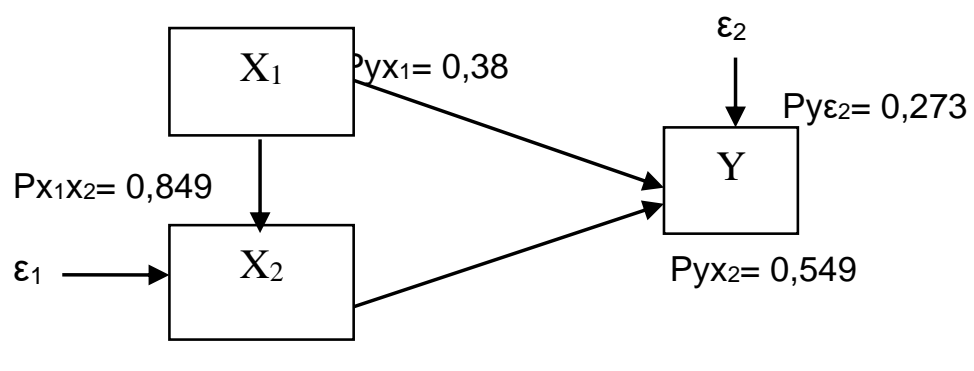

$\mathrm{P}_{\mathrm{X}_{2} \varepsilon_{1}}=0,151$

Gambar 1 Struktur hubungan pengaruh lingkungan kerja dan disiplin kerja terhadap kinerja karyawan pada CV Puspa

Tabel 2 Sumbangan pengaruh lingkungan kerja $\left(\mathrm{X}_{1}\right)$ dan disiplin kerja $\left(\mathrm{X}_{2}\right)$ terhadap kinerja karyawan (Y) pada CV Puspa

\begin{tabular}{lcc}
\hline Keterangan & Besar & Persentase \\
\hline Besar pengaruh langsung $\mathrm{X}_{1}$ terhadap $\mathrm{Y}$ & 0,94 & $9,4 \%$ \\
\hline $\begin{array}{l}\text { Besar pengaruh tidak langsung } \mathrm{X}_{1} \text { dan } \mathrm{X}_{2} \\
\text { terhadap } \mathrm{Y}\end{array}$ & 0,466 & $46,6 \%$ \\
\hline Besar pengaruh total $\mathrm{X}_{1}$ terhadap $\mathrm{Y}$ & 0,451 & $45,1 \%$ \\
\hline Besar pengaruh langsung $\mathrm{X}_{2}$ terhadap $\mathrm{Y}$ & 0,301 & $30,1 \%$ \\
\hline Besar pengaruh total $\mathrm{X}_{1}$ dan $\mathrm{X}_{2}$ terhadap $\mathrm{Y}$ & 0,763 & $76,3 \%$ \\
\hline Besar pengaruh lain terhadap $\mathrm{Y}$ & 0,237 & $23,7 \%$ \\
\hline Total & 1,000 & $100 \%$ \\
\hline Sumber : Pengelolaan Data SPSS & &
\end{tabular}

Berdasarkan penelitian yang dilakukan, maka diperoleh temuan bahwa variabel lingkungan kerja $\left(X_{1}\right)$ dan disiplin kerja $\left(X_{2}\right)$ berpengaruh secara positif dan signifikan terhadap kinerja karyawan $\left(\mathrm{X}_{2}\right)$ pada CV Puspa. Hal ini didukung oleh teori yang diungkapkan oleh Sumadji dan Suartman (2017), menyatakan bahwa adanya lingkungan kerja yang memadai dan kondusif serta karyawan yang disiplin dalam menaati peraturan diharapkan kinerja karyawan bisa meningkat. Hal ini juga didukung penelitian yang dilakuakan oleh Ferawati (2017), menunjukan bahwa lingkungan kerja dan disiplin kerja berpengaruh signifikan terhadap kinerja karyawan. Hasil penelitian ini dibuktikan dari belum tercapainya standar kinerja yang telah ditetapkan perusahaan. Hal ini disebabkan karena lingkungan kerja yang tidak nyaman dilihat dari fasilitas penerangan ruangan, pentilasi udara dan kebersihan ruangan yang masih sangat kurang serta hubungan antar rekan kerja, bawahan dan atasan yang masih kurang harmonis. Disamping itu, variabel disiplin kerja yang terapkan dalam perusahaan masih rendah seperti ketidakhadiran karyawan yang masih tinggi, keterlambatan masuk kerja dan memanfaatkan waktu istirahat berlebihan. Oleh karena itu, pihak CV Puspa perlu segera melakukan perbaikan dan evaluasi terkait lingkungan kerja dan disiplin kerja guna meningkatkan kualitas sumber daya manusia sehingga mencapai tujuan perusahaan. Hal ini memberikan implikasi bahwa karyawan yang merasa nyaman dengan lingkungan kerja karena didukung oleh kelengkapan fasilitas dan keharmonisan hubungan antar rekan kerja, bawahan dan atasan akan mengoptimalkan kinerja dan menaati peraturan yang telah dibuat perusahaan melalui disiplin kerja. Upaya peningkatan kinerja karyawan dapat dilakukan dengan mengoptimalkan kebijakan yang berkaitan dengan variabel lingkungan kerja dan disiplin kerja. 
Hasil penelitian menunjukkan bahwa lingkungan kerja $\left(X_{1}\right)$ berpengaruh secara positif dan signifikan terhadap terhadap disiplin kerja $\left(\mathrm{X}_{2}\right)$ pada CV Puspa. Hal ini didukung oleh teori yang diungkapkan Supriyanto dan Sukir (2007: 26), yang menyatakan dengan lingkungan kerja yang menyenangkan maka diharapkan karyawan cenderung akan bekerja dengan sikap disiplin yang tinggi, semangat dan memiliki rasa tanggung jawab terhadap tugas pekerjaannya dan merasa tidak ada yang mengganggu. Hal ini juga didukung oleh penelitian yang dilakukan Inbar, dkk (2018), yang menyatakan bahwa terdapat pengaruh yang positif dan signifikan dari lingkungan kerja terhadap disiplin kerja. Lingkungan kerja yang nyaman disertai dengan fasilitas yang memadai dan hubungan yang harmonis antar rekan kerja, bawahan dan atasan sangat memengaruhi peningkatan disiplin kerja. Fasilitas yang lengkap akan membantu perusahaan dalam pengawasan disiplin kerja dan pelanggaran disiplin kerja akan berdampak pada pemberian sanksi sosial terhadap karyawan. Oleh karena itu, pihak CV Puspa perlu memperhatikan variabel lingkungan kerja dan disiplin kerja guna meningkatkan kinerja karyawan. Hal ini memberikan implikasi bahwa lingkungan kerja dapat mendukung terciptanya disiplin kerja. Fasilitas yang memadai dan suasana kerja yang kondusif akan mampu menimbulkan gairah dan semangat kerja yang tinggi sehingga karyawan melaksanakan tugasnya dengan disiplin kerja yang tinggi. Pihak CV Puspa sangat perlu melakukan perbaikan dan evaluasi untuk mencapai tujuan perusahaan melalui kedua variabel ini yaitu lingkungan kerja dan disiplin kerja.

Hasil penelitian menunjukkan bahwa variabel lingkungan kerja $\left(X_{1}\right)$ berpengaruh terhadap kinerja karyawan (Y) pada CV Puspa. Hal ini sejalan dengan teori yang diungkapkan oleh Rahmawati, dkk., (2014), yang menyatakan lingkungan kerja yang nyaman, aman dan menyenangkan merupakan salah satu cara perusahaan untuk dapat meningkatkan kinerja para karyawan. Hal ini di dukung oleh penelitian yang dilakukan oleh Nuryasin, dkk., (2016), yang menyatakan bahwa variabel lingkungan kerja berpengaruh signifikan terhadap kinerja karyawan. Lingkungan kerja yang nyaman yang tercipta melalui hubungan yang harmonis antar rekan kerja, bawahan dan atasan serta didukung oleh fasilitas yang memadai. Lingkungan kerja seperti ini akan memberikan dampak positif pada karyawan sehingga memengaruhi kinerja karyawan. Hal tersebut sependapat dengan hasil penelitian yang diperoleh. Hasil penelitian ini dibuktikan dengan belum tercapainya standar kinerja yang telah ditetapkan perusahaan sebelumnya. Jika dilihat dari sisi lingkungan kerja fisik, karyawan merasa tidak nyaman dalam bekerja karena fasilitas keja yang belum memadai seperti pencahayaan di ruang kerja yang kurang maksimal yang disebabkan karena sedikit lampu yang terpasang didalam ruangan tersebut, minimnya pentilasi udara pada ruang, penataan ruangan yang kurang rapi dan kurangnya kebersihan dalam lingkungan kerja. Selain lingkungan kerja fisik lingkungan kerja non fisik juga dapat mempengaruhi kinerja karyawan terlihat pada tidak tercapainya hubungan yang baik antara karyawan atupun atasan dikarenakan sering tercadinya miss comunication dalam pendistribusian produk dan perilaku sosial yang sering curiga dengan sesama karyawan. Jika kondisi lingkungan kerja fisik maupun lingkungan kerja non fisik yang ada di perusahaan tidak diperbaiki hal ini akan berdampak penurunan kinerja karyawan. Oleh karena itu, pihak CV Puspa perlu melakukan evaluasi dan pembenahan dalam segi fasilitas kerja dan menciptakan hubungan yang harmonis antar rekan kerja, bawahan dan atasan sehingga lingkungan kerja menjadi nyaman dan dapat meningkatkan kinerja karyawan dalam mencapai tujuan perusahaan yang telah ditetapkan. Hal ini memberikan implikasi bahwa lingkungan kerja mampu memberikan kenyamanan dan rasa semangat dalam bekerja bagi karyawan. Dengan hal tersebut karyawan akan memaksimal kinerja yang dimiliki untuk memberikan kontribusinya kepada perusahaan. Upaya peningkatan lingkungan kerja yang telah dilakukan diantaranya dengan membersihkan area kerja karyawan dan mengadakan kegiatan bersama antar rekan kerja, bawahan dan atasan setiap setahun sekali. Upaya tersebut masih belum optimal sehingga perlu upaya lain yang bertujuan untuk meningkatkan lingkungan kerja karyawan diantaranya melakukan pemeriksaan fasilitas kerja seperti jendela, AC, lampu ruangan dan peralatan kebersihan setiap sebulan sekali, mengganti 
fasilitas yang rusak, melakukan penataan ulang dengan nuansa yang baru setiap tahunnya dan meningkatkan aktivitas bersama rekan kerja, bawahan dan atasan setiap sebulan sekali.

Hasil penelitian selanjutnya yang diperoleh adalah variabel disiplin kerja $\left(X_{2}\right)$ akan berpengaruh secara positif dan signifikan terhadap kinerja karyawan ( $Y$ ) pada CV Puspa. $\mathrm{Hal}$ ini juga didukung oleh teori yang diungkapkan Winarto dan Laela (2016), yang menyatakan kedisiplinan merupakan fungsi operatif keenam dari para manajemen sumber daya manusia yang terpenting yang perlu diperhatikan oleh perusahaan, karena semakin baik disiplin karyawan, maka semakin baik pula kinerjanya. Hal ini juga didukung oleh penelitian empirik yang dilakukan oleh Winarto dan Laela (2016), yang menyatakan variabel disiplin kerja berpengaruh secara positif dan signifikan terhadap kinerja karyawan. Disiplin kerja sangat memengaruhi pencapaian kinerja perusahaan terhadap target yang telah ditetapkan. Apabila karyawan tidak disiplin dalam bekerja maka hasil yang diperoleh tidak akan optimal. Dampak dari ketidakdisiplinan dalam bekerja tidak hanya merugikan perusahaan tetapi juga mencerminkan kualitas sumber daya manusia dari perusahaan yang bersangkutan. Hasil penelitian ini dibuktikan dengan kurangnya disiplin karyawan yang menyebabkan kinerja karyawan rendah. Hal tersebut dapat dilihat dari ketidakhadiran karyawan, keterlambatan masuk kerja, pulang tidak sesaui waktu, dan karyawan sering mengulur pada waktu istirahat sehingga mempengaruhi tingkat kinerja karyawan dalam mencapai tujuan organiasi perusahaan. Apabila perusahaan tidak berupaya dalam peningkatan disiplin kerja maka perusahaan akan mendapat kerugian dari adanya penurunan kinerja. Oleh karena itu, pihak CV Puspa perlu melakukan perbaikan dalam kebijakan dan sanksi terhadap karyawan yang melanggar aturan kerja. Sumbangan pengaruh disiplin kerja $\left(X_{2}\right)$ terhadap kinerja karyawan lebih besar dibandingkan dengan lingkungan kerja $\left(X_{1}\right)$. Hal tersebut dikarenakan pelaksanaan disiplin kerja lebih memerlukan perhatian lebih dibandingkan lingkungan kerja. Apabila karyawan melaksanakan disiplin kerja maka kinerja karyawan akan meningkat. Peningkatan ini akan memberikan laba perusahaan yang tinggi sehingga fasilitas kerja dapat terpenihi dan kegiatan yang bertujuan untuk menjalin hubungan ang harmonis atar rekan kerja, bawahan dan atasan dapat dilaksanakan. Hal ini memberikan implikasi bahwa semakin disiplin karyawan dalam menjalankan tugas perusahaan maka semakin meningkat pula kinerja perusahaan tersebut. Ketidakdisiplinan karyawan hanya akan membawa dampak buruk khususnya pada lini-lini perusahaan yang menyebabkan standar kinerja karyawan tidak tercapai. Apabila hal ini dibiarkan maka hal tersebut sangat berpengaruh pada aktivitas perusahaan selanjutnya. Upaya yang telah dilakukan oleh perusahaan untuk meningkatkan disiplin kerja diantaranya adalah mencatat kehadiran karyawan, menetapkan SOP perusahaan dan memberikan sanksi terhadap pelanggaran yang dilakukan oleh karyawan. Namun, pelaksanaannya masih belum optimal, pihak CV Puspa perlu melakukan evaluasi secara berkala terhadap disiplin karyawan dan melakukan perbaikan terhadap SOP perusahaan yang kurang tegas sehingga sanksi yang ditetapkan memberikan efek jera kepada karyawan.

\section{Simpulan dan Saran}

Berdasarkan hasil dan pembahasan yang diakukan, dapat ditarik simpulan yaitu, (a) lingkungan kerja dan disiplin kerja berpengaruh secara positif dan signifikan terhadap kinerja karyawan kerja pada CV Puspa, (b) lingkungan kerja berpengaruh secara positif dan signifikan terhadap disiplin kerja pada CV Puspa, (c) lingkungan kerja berpengaruh secara positif dan signifikan terhadap kinerja karyawan pada CV Puspa, dan (d) disiplin kerja berpengaruh secara positif dan signifikan terhadap kinerja karyawan pada CV Puspa.

Berdasarkan simpulan yang telah dikemukakan, maka dapat diajukan beberapa saran yaitu, (a) bagi pihak manajemen CV Puspa diharapkan mampu meningkatkan kinerja karyawan melalui peningkatan lingkungan kerja dan disiplin kerja. Peningkatan lingkungan kerja dapat dilakukan melalui pemeriksaan dan perawatan fasilitas perusahaan seperti AC, pentilasi udara dan peralatan kebersihan. Disamping itu, penciptaan suasana kerja yang nyaman diperlukan melalui hubungan yang harmonis antar rekan kerja, bawahan dan atasan. Peningkatan disiplin kerja dapat dilakukan dengan meningkatkan pengawasan dalam 
kehadiran karyawan, mengevaluasi SOP perusahaan dan memberikan sanksi yang tegas bagi karyawan yang melanggar sehingga tidak dicontoh oleh karyawan yang lain. Upaya ini sangat penting dilakukan untuk meningkatkan laba perusahaan guna mencapai tujuan yang telah ditetapkan. dan (b) bagi peneliti selanjutnya, khususnya yang tertarik dan berminat untuk mendalami tentang lingkungan kerja dan disiplin kerja terhadap kinerja karyawan diharapkan untuk mengembangkan penelitian ini dengan menambahkan sampel yang lebih luas agar dapat menguji variabel lainnya yang diduga kuat dapat memengaruhi kinerja karyawan.

\section{Daftar Pustaka}

Ardana, I Komang. 2012. Manajemen Sumber Daya Manusia. Yogyakarta: Graha Ilmu.

Bernardin, John H dan Russel, Joyce E. A. 1993. Human Resources Managment: An Experiental Approach. Jakarta: Gramedia Pustaka.

Ferawati, Apria. 2017. "Pengaruh Lingkungan Kerja dan Disiplin Kerja Terhadap Kinerja Karyawan". Agora, Volume 5, Nomber 1 (hal 3).

Hasibuan, Melayu SP. 2012. Manajemen Sumber Daya Manusia. Jakarta: PT. Bumi Aksara. Inbar, Noor. 2018. "Pengaruh Ligkungan Kerja Terhadap Disiplin Kerja Dan Semangat Kerja Karyawan (Studi Pada Karyawan PDAM Kota malang)". Administrasi Bisnis, Volume 58, Nomber 2 (hal. 85).

Mangkunegara, Anwar Prabu. 2011. Manajemen Sumber Daya Manusia. Bandung: PT. Remaja Rosdakarya.

Nitisemito S.A. 2008. Manajemen Personalia Edisi Delapan. Jakarta: Ghalida Indonesia.

Nuryasin. 2016. "Pengaruh Lingkungan Kerja dan Motivasi Kerja Terhadap Kinerja Karyawan

(Studi Pada Karyawan Perusahaan Daerah Air Minum (PDAM) Kota Malang)". Jurnal Administrasi Bisnis, Volume 41, Nomber 1 (hal. 21).

Putra, I Wayan Indra. 2014. "Pengaruh Tingkat Pendidikan dan Disiplin Kerja Terhadap Kinerja Karyawan". E-journal Bisma Universitas Pendidikan Ganesha, Volume 4.

Rahmawati. 2014 ."Pengaruh Lingkungan Kerja Terhadap Kinerja Karyawan (Studi pada Karyawan Kantor Pelayanan Pajak Pratama Malang Utara)". Jurnal Administrasi Bisnis, Volume 8, Nomber 2 (hal. 2).

Rivai, V. 2004. Kepemimpinan dan Perilaku Organisasi. Edisi Kedua. Jakarta: PT Raja Grafindo Persada.

Sastrohadiwiryo, Siswanto. 2003. Manajemen Tenaga Kerja Indonesi, Cetakan Kedua. Jakarta: PT. Bumi Aksara.

Saydam. G. 2000. Manajemen Sumber Daya Manusia (human resources management). Jakarta: Djambatan.

Sedarmayanti, 2007. Sumber Daya Manusia dan Produktivitas Kerja. Bandung: Penerbit Mandar Maju. 
Sidanti, Heny. 2015. Pengaruh Lingkungan Kerja dan Disiplin Kerja Terhadap Kinerja Pegawai Negeri Sipil di Sekretariat Dprd Kabupaten Maduin". Jurnal JIMBEKA. Volume 9, Nomber 1 (hal. 44-53).

Sinambela, Lijan Poltak. 2012. Kinerja Pegawai. Yogyakarta : Graha IImu

Singodimedjo, M. 2002. Manajemen sumber daya manusia. Surabaya: SMMAS.

Sugiyono. 2010. Statistik Untuk Penelitian. Bandung : CV. Alfabeta.

Sugiyono. 1999. Metode Penelitian Bisnis. Bandung: CV. Alfabeta.

Sumadji, Mochamad dan Bambang Suratman. 2017. "Pengaruh Lingkungan Kerja dan Disiplin Kerja Terhadap Kinerja Karyawan di PT. Envilab Kabupaten Gersik”. Jurnal Administrasi Perkantoran, Volume 5, Nomber 3 (hal. 3).

Supriyanto, dan Sukir. 2007. "Pengaruh Disiplin Kerja, Lingkungan Kerja dan Motivasi Kerja Terhadap Kinerja Karyawan”. Jurnal Manajemen Sumber Daya Manusia, Volume 4 (hal. 26).. Wibowo. 2012. Manajemen Kinerja. Jakarta: Rajawali Pers.

Winarto, Charles Adi dan Siti Laela. 2016. “ Pengaruh Pelatihan dan Disiplin Kerja Terhadap Kinerja Karyawan Bengkel Nissan Cibubur". Jurnal Pengembang Wiraswasta, Volume 18, Nomber 3 (hal. 267)

Zainul, H dan Taufiq. 2012. "Pengaruh Lingkungan Kerja Dan Disiplin Kerja Serta Motivasi Kerja Terhadap Kinerja Perusahaan Daerah Air Minum (PDAM) Kabupaten Lumajang". Jurnal WIGA Vol. 2, Nomber 1 (hal. 79-97). 